\title{
Effectiveness of teaching strategies on the development of critical thinking in undergraduate nursing students: a meta-analysis*
}

\author{
Efetividade das estratégias de ensino no desenvolvimento do pensamento \\ crítico de graduandos de enfermagem: uma metanálise \\ Efectividad de las estrategias de enseñanza en el desarrollo del pensamiento \\ crítico de estudiantes de pregrado de enfermería: un metaanálisis
}

Larissa Bertacchini de Oliveira ${ }^{1,2,3}$, Leidy Johanna Rueda Díaz ${ }^{1,4}$, Fábio da Costa Carbogim ${ }^{1,2,5}$, Adriano Rogério Baldacin Rodrigues $^{3}$, Vilanice Alves de Araújo Püschel ${ }^{1,2,3}$

How to cite this article:

Oliveira LB, Rueda Díaz LJ, Carbogim FC, Rodrigues ARB, Püschel VAA. Effectiveness of teaching strategies on the development of critical thinking in undergraduate nursing students: a meta-analysis. Rev Esc Enferm USP. 2016;50(2):350-359. DOI: http://dx.doi.org/10.1590/S0080-623420160000200023

\footnotetext{
* Extracted from the dissertation, "Efetividade das estratégias de ensino para o desenvolvimento do pensamento crítico em estudantes de graduação em Enfermagem: revisão sistemática e metanálise", Programa de Pós-graduação em Enfermagem na Saúde do Adulto, Escola de Enfermagem, Universidade de São Paulo, 2014.

${ }^{1}$ Universidade de São Paulo, Escola de Enfermagem, Programa de Pós-graduação em Enfermagem na Saúde do Adulto, São Paulo, SP, Brazil.

${ }^{2}$ Red Iberoamericana de Investigación en Educación en Enfermería (RIIEE) - Region Brazil.

${ }^{3}$ Centro Brasileiro para o Cuidado à Saúde Baseado em Evidências, Centro Colaborador do Instituto Joanna Briggs (JBI - Brazil), Universidade de São Paulo, Escola de

Enfermagem, Hospital Universitário, São Paulo, SP, Brazil.

${ }^{4}$ Universidad Industrial de Santander, Bucaramanga, Colombia.

${ }^{5}$ Universidade Federal de Juiz de Fora, Juiz de Fora, MG, Brazil.
}

\begin{abstract}
Objective: To evaluate the effectiveness of teaching strategies used for development of critical thinking (CT) in undergraduate nursing students. Method: Systematic review with meta-analysis based on the recommendations of the Joanna Briggs Institute. Searches were conducted in the following databases: PubMed, CINAHL, EMBASE, Web of Science, SCOPUS, LILACS, Cochrane CENTRAL, PsycINFO, ERIC, and a database of theses from four continents. The initial selection and evaluation of studies and assessment of methodological quality was performed by two reviewers independently. Results: Twelve randomized clinical trials were included in the study. In the metaanalysis of the four studies included that evaluated the strategy of problem-based learning (PBL), compared to lectures, the effectiveness of PBL was demonstrated with statistical significance $(\mathrm{SMD}=0.21$ and $95 \% \mathrm{CI}=0.01$ to $0.42 ; \mathrm{p}=0.0434$ ) for the development of CT in undergraduate nursing students, and the studies were homogeneous (chisquare $=6.10, p=0.106$ ). Conclusion: The effectiveness of PBL was demonstrated in the increase of overall CT scores. Further studies need to be conducted in order to develop, implement and evaluate teaching strategies that are guided in high methodological rigor, and supported in theoretical models of teaching and learning.
\end{abstract}

\section{DESCRIPTORS}

Thinking; Students, Nursing; Education, Nursing; Randomized Controlled Trial; Review. 


\section{INTRODUCTION}

It is increasingly important to train professionals that are critical, reflective, and able to make complex decisions based on knowledge of scientific evidence ${ }^{(1)}$. In this context, development of critical thinking (CT) skills has become a prerequisite for safe and effective clinical practice ${ }^{(2)}$, given the demonstrated positive and significant correlation between CT and problem solving ${ }^{(3)}$.

Critical thinking is an essential tool for nursing education, and its acquisition is one of the most desired results of higher education today ${ }^{(7)}$. CT should not be confused with intelligence; instead, it should be understood as a skill that can be taught ${ }^{(4)}$ by developing logical and consistent thinking ${ }^{(5)}$ that involves both cognitive and behavioral components ${ }^{(6)}$.

Critical thinking has been much discussed in nursing literature ${ }^{(8-9,4)}$, and is considered one of the most important concepts in education $^{(10)}$. Several studies ${ }^{(3,7,10-11)}$ have emphasized the importance of preparing educators to teach CT skills through implementing active and innovative teaching strategies. Failure to teach CT at the university level can produce health care professionals devoid of this skill, which carries drastic consequences for the safety and proper treatment of patients in health care settings ${ }^{(11)}$.

Experimental studies have shown favorable results from strategies for Problem-Based Learning (PBL) ${ }^{(12-14)}$ and the concept map ${ }^{(15-16)}$ in developing CT in nursing students. However, no systematic reviews (SR) of quantitative studies that sought to evaluate the effectiveness of these strategies were identified in the literature; thus, the need was indicated for an SR on qualitative studies of $\mathrm{CT}^{(9)}$. The authors of the present study identified SR on specific teaching strategies such as $\mathrm{PBL}^{(17-18)}$ and simulation ${ }^{(19)}$, which considered CT one of the outcomes assessed. In addition, only one $\mathrm{SR}^{(17)}$ was identified that assessed the effectiveness of a teaching strategy for development of CT according to the variables and effect size in a meta-analysis.

Therefore, given the importance of training nurses capable of thinking critically, the Latin American Network for Research in Nursing Education (Red Iberoamericana de Investigación en Educación en Enfermería - RIIEE) has addressed this issue in a multicenter research project carried out in 16 countries in Latin America, and the present study is part of this project. Investigation of CT in an international research network enabled the authors to identify the need to synthesize evidence available in the literature on effective teaching strategies for development of CT. Thus, this study aimed to evaluate the effectiveness of teaching strategies for the development of CT in undergraduate nursing students. The following research questions were considered: What teaching strategies have been used and tested by randomized clinical trials to promote CT in undergraduate nursing education? and What is the effectiveness of teaching strategies to develop CT in undergraduate nursing students?

\section{METHOD}

Systematic review and meta-analysis guided by recommendations of the Joanna Briggs Institute ${ }^{(20)}$ and the
Preferred Reporting Items for Systematic Reviews and MetaAnalyses (PRISMA) ${ }^{(21)}$. The SR protocol was published in the JBI Library ${ }^{(22)}$, and registered in the database International Prospective Register of Systematic Reviews (PROSPERO) ${ }^{(23)}$.

\section{DATABASE SEARCHES AND SELECTION OF STUDIES}

A preliminary search in the databases Cochrane Database of Systematic Reviews, Joanna Briggs Institute Library of Systematic Reviews, JBI COnNECT+, Database of Abstracts of Reviews of Effects (DARE), PubMed and PROSPERO yielded two $\mathrm{SR}^{(14,19)}$ and one SR protocol ${ }^{(24)}$ on the effectiveness of teaching strategies for the development of CT in nursing students. However, none of these studies was designed based on the aims of the present study.

Inclusion criteria for the present SR were: studies of randomized clinical trials (RCT); published in full in Portuguese, Spanish or English; and, having the aim of researching the effectiveness of teaching strategies on development of CT. Studies that did not show the abstract in full online in the databases searched, and those for which the full text was not obtained online or in the bibliographic archive, or after direct contact with the authors of the manuscript were excluded. No time limit was set for the search.

The PICOS strategy $(\mathrm{P}$ - population; I - intervention; $\mathrm{C}$ - comparison; $\mathrm{O}$ - outcomes and $\mathrm{S}-$ study) guided the development of the leading question of the SR, and was the basis for development of search strategies, so that the synonyms of each PICO component were combined using the Boolean operator "OR" and the components of the acronym were combined with the Boolean operator "AND". Undergraduate nursing students in any stage in the course were considered the study population. Teaching strategies used to develop CT were considered the study intervention. Studies that used a specific teaching strategy or traditional teaching or no specific intervention on the control group were considered the comparison. CT was considered the outcome, which was analyzed through skills and dispositions, and evaluated by means of CT measurement scales ${ }^{(25)}$. RCTs were considered for inclusion in the study.

Preliminary searches in the PubMed portal and CINAHL database were conducted to identify controlled and uncontrolled terms contained in the titles and abstracts of the studies. The searches were carried out by two reviewers independently, and the terms and search strategies developed by the primary reviewer were validated by the secondary reviewer and a librarian.

The search was conducted from September to December 2014. The databases used were PubMed, CINAHL, EMBASE, Web of Science, SCOPUS, LILACS, Cochrane CENTRAL, PsycINFO and ERIC. Thesis and dissertation databases from four continents (Africa, America, Europe and Australia) were used to search the gray literature: ProQuest Dissertations and Theses, Cybertesis, Digital Library of Theses and Dissertations of the University of São Paulo (Biblioteca Digital de Teses e Dissertações da Universidade de São Paulo - Brazil), Australian Digital Theses (ADT), Open Access Scientific Repository of Portugal (Repositório Cientifico de Acesso Aberto de Portugal- RCAAP), Academic 
Archive On-Line (DiVA), Theses Canada, Electronic Theses Online Service (EThOS), DART-Europe E-Theses Portal and the National ETD Portal. The terms used for the search included: P - "nursing student", "undergraduate", "baccalaureate"; I and C - "teaching methods", "learning, problem-based", "simulation", "case study", "concept maps", "lectures"; O - "thinking", "critical thinking”; S - "randomized controlled trial", "experimental", "evaluation study".

Selection of studies by title, abstracts and full reading was performed by the primary and secondary reviewers independently. The studies that generated some disagreement between the reviewers for inclusion were discussed with a third reviewer.

\section{ASSESSMENT OF METHODOLOGICAL QUALITY AND DATA EXTRACTION}

CREMS version 5.02C and JBI-MAStARI were used to analyze the methodological rigor of the studies included, which was performed by two reviewers independently. The studies were evaluated using the Critical Appraisal Tools Randomized Control Trial/Pseudo-randomized Trial (MAStARI), the instrument for critical evaluation of randomized and controlled clinical trials. The instrument assessed whether the study participants were randomized; if the researcher who allocated the subjects and what was evaluated was blinded, as well as the study participants; analysis by intention to treat; if the subjects of the intervention and control groups at baseline were compared; if the groups were identically treated, except for the intervention group; if measurement of results in the control and intervention groups was identical and reliable; and finally, whether statistical analysis was appropriate. Studies that obtained a score of seven or higher of ten items evaluated were included, since the JBI leaves definition of this cut-off point for inclusion of studies to the researcher's criteria ${ }^{(20)}$.

After assessment of methodological quality, data extraction of studies selected for the SR was performed by two reviewers using the MAStARI data extraction instrument, in order to ensure the accuracy of the findings. The extracted data included details of the study population, intervention, inclusion and exclusion criteria and study results. Data that were not identified in the studies were obtained through contact with authors.

\section{SUMMARY OF DATA AND STATISTICAL ANALYSIS}

The results were presented descriptively, and studies evaluating the same teaching strategies and that presented homogeneity in their design were combined to carry out the statistical meta-analysis using the MIX 2.0 Pro software.

The standardized mean difference (SMD) is the difference between two means, divided by an estimate of the standard deviation between the groups, and is used when the outcome is assessed by different scales ${ }^{(20,26)}$. In the analysis of continuous variables with outcomes considered desirable, an $\mathrm{SMD}>0$ indicates that the intervention was favorable (statistically significant), and that the results appear to the right of the forest plot $^{(20,26)}$.
The effect size (Overall $Z$ ) is a generic term for estimating the effect of a study, so that researchers can say that the effect of the intervention is significant when it has a value of $\mathrm{p}$ less than $0.05^{(20,26)}$. In contrast, the heterogeneity of the studies was assessed using the standard Chi-square, which is estimated by the method of inverse variance. Thus, studies are considered homogeneous when the value of $p$ is greater than $0.05^{(20)}$.

Since the studies included evaluated CT through different scales and were considered homogeneous, the effect size was assessed by the fixed effects model, standardized mean difference (SMD), and 95\% confidence intervals were calculated for analysis.

\section{RESULTS}

A total of 2,949 studies were found in the selected databases and by means of cross-reference strategy. 557 duplicates were excluded, and 78 studies were completely evaluated. After assessment of the methodological quality, 12 RCT were selected that comprised the final sample of this SR, as noted in the flowchart in Figure 1.

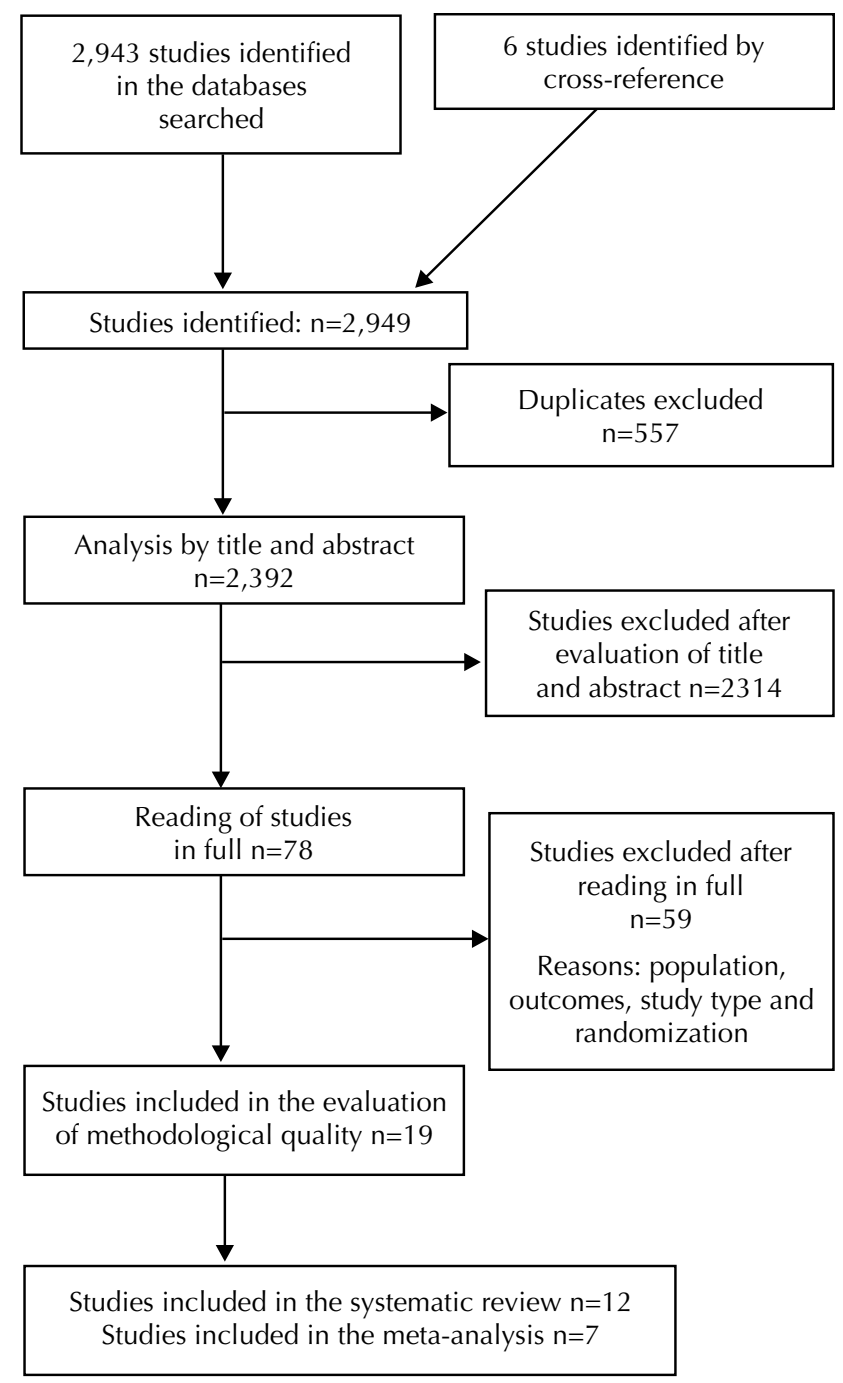

Figure 1 - Flowchart of inclusion of studies - São Paulo, Brazil, 2015. 


\section{ChARACTERISTICS OF STUDIES}

All studies were published in English and had a level of evidence II, according to the JBI classification of quantitative studies(20); 50\% were carried out in the United States and $33 \%$ in China; $75 \%$ were published in article format; $83 \%$ had grade 7 according to the JBI-MAStARI instrument; and, $66 \%$ of the studies were developed in the last five years. The complete characterization of the studies included is described in Chart 1.

Chart 1 - Characterization of the studies included - São Paulo, Brazil, 2015.

\begin{tabular}{|c|c|c|c|c|c|c|}
\hline $\begin{array}{l}\text { Author (Year) } \\
\text { (country) }\end{array}$ & Sample size & Intervention & Comparison & $\begin{array}{l}\text { Duration of } \\
\text { intervention }\end{array}$ & $\begin{array}{c}\text { Measurement } \\
\text { tools }\end{array}$ & Results \\
\hline $\begin{array}{l}\text { Tiwari } \\
\text { et al. }(2006) \\
(\text { China })^{(27)}\end{array}$ & $\begin{array}{l}79 \text { first-year } \\
\text { students }\end{array}$ & $\begin{array}{l}\text { Problem-based learning } \\
\text { (PBL) }\end{array}$ & Lectures & 2 semesters & $\begin{array}{c}\text { California } \\
\text { Critical Thinking } \\
\text { Disposition } \\
\text { Inventory (CCTDI) }\end{array}$ & $\begin{array}{l}\text { The PBL group had overall } \\
\text { CT scores measured by } \\
\text { the CCTDI that were } \\
\text { significantly higher } \\
\text { than the lectures group } \\
\quad(p=0.005)\end{array}$ \\
\hline $\begin{array}{l}\text { Ferguson } \\
(2012) \\
(\text { USA })^{(28)}\end{array}$ & $\begin{array}{l}57 \text { first-year } \\
\text { students }\end{array}$ & $\begin{array}{l}\text { Two groups were used: } \\
1 \text { - Traditional lectures + } \\
\text { microsimulation + Human } \\
\text { Patient Simulation (HPS) } \\
2 \text { - Traditional lectures + } \\
\text { Microsimulation + HPS, } \\
\text { and after one week a new } \\
\text { HPS session without the } \\
\text { mentor was performed }\end{array}$ & $\begin{array}{l}\text { Used lectures } \\
\text { and micro- } \\
\text { simulation }\end{array}$ & 2 weeks & $\begin{array}{l}\text { Watson Glaser } \\
\text { Critical Thinking } \\
\text { Appraisal } \\
\text { (WGCTA) }\end{array}$ & $\begin{array}{l}\text { There was no statistically } \\
\text { significant difference in } \\
\text { overall CT score on the } \\
\text { pre-test and post-test } \\
\text { examination for all groups }\end{array}$ \\
\hline $\begin{array}{l}\text { Atay \& } \\
\text { Karabacak } \\
(2011) \\
\text { (Turkey) }^{(15)}\end{array}$ & $\begin{array}{l}80 \text { first-and } \\
\text { second- year } \\
\text { students }\end{array}$ & $\begin{array}{c}\text { Concept map in the } \\
\text { development of nursing } \\
\text { care plans }\end{array}$ & $\begin{array}{l}\text { Traditional } \\
\text { method using } \\
\text { column format }\end{array}$ & 1 semester & CCTDI & $\begin{array}{l}\text { There was no statistically } \\
\text { significant difference } \\
\text { between the groups. In the } \\
\text { experimental group, the } \\
\text { difference on the pre- and } \\
\text { post-test was statistically } \\
\text { significant }(p=0.000)\end{array}$ \\
\hline $\begin{array}{l}\text { Jun et al. } \\
(2013)(\text { South } \\
\text { Korea) })^{(29)}\end{array}$ & $\begin{array}{l}161 \\
\text { second-year } \\
\text { students }\end{array}$ & $\begin{array}{l}\text { 5E learning model } \\
\text { combined with PBL }\end{array}$ & $\begin{array}{l}\text { Lectures and } \\
\text { discussion } \\
\text { groups }\end{array}$ & 5 weeks & $\begin{array}{l}\text { Critical Thinking } \\
\text { Disposition } \\
\text { Scale for Nursing } \\
\text { Students }\end{array}$ & $\begin{array}{l}\text { Significant increase in } \\
\text { capacity for CT }(p=0.005) \\
\text { in the experimental group }\end{array}$ \\
\hline $\begin{array}{l}\text { Naber \& } \\
\text { Wyatt (2014) } \\
(\text { USA })^{(30)}\end{array}$ & $\begin{array}{l}70 \text { first-year } \\
\text { students }\end{array}$ & $\begin{array}{c}\text { Reflective writing based } \\
\text { on Richard Paul's CT } \\
\text { Model }\end{array}$ & $\begin{array}{l}\text { There was no } \\
\text { intervention, } \\
\text { the traditional } \\
\text { method already } \\
\text { used in the } \\
\text { discipline was } \\
\text { used }\end{array}$ & 8 weeks & $\begin{array}{l}\text { California Critical } \\
\text { Thinking Skills } \\
\text { Test (CCTST) and } \\
\text { CCTDI }\end{array}$ & $\begin{array}{l}\text { No significant differences } \\
\text { were observed in CT } \\
\text { scores measured by the } \\
\text { CCTDI }(p=0.690) \text { and } \\
\text { CCTST }(p=0.260)\end{array}$ \\
\hline $\begin{array}{l}\text { Ousley } \\
(2012) \\
(\text { USA) }\end{array}$ & $\begin{array}{l}132 \\
\text { second-year } \\
\text { students }\end{array}$ & $\begin{array}{l}\text { Two groups were used: } \\
1 \text { - Lecture }(4 \text { hours })+ \\
\text { Simulation }(8 \text { hours })+32 \\
\text { hours of clinical practice } \\
2 \text { - Lecture }(4 \text { hours }) \\
+ \text { Online Case Studies } \\
\text { (8 hours) }+32 \text { hours of } \\
\text { clinical practice }\end{array}$ & $\begin{array}{l}\text { Only lectures } \\
(12 \text { hours })+ \\
32 \text { hours of } \\
\text { practice. }\end{array}$ & 4 weeks & CCTST & $\begin{array}{l}\text { All groups showed } \\
\text { significant changes on } \\
\text { the pre- and post-test for } \\
\text { overall CT }(p<0.010)\end{array}$ \\
\hline $\begin{array}{l}\text { Wheeler } \\
\text { and Collins } \\
(2003) \\
(\text { USA) })^{(16)}\end{array}$ & $\begin{array}{l}76 \\
\text { second-year } \\
\text { students }\end{array}$ & Concept maps & $\begin{array}{l}\text { Traditional } \\
\text { method }\end{array}$ & 7.5 weeks & CCTST & $\begin{array}{l}\text { There was no significant } \\
\text { statistical difference. In } \\
\text { the experimental group } \\
\text { significant difference of } \\
\text { overall CT was found } \\
\text { between the pre- and } \\
\text { post-test }(p=0.020)\end{array}$ \\
\hline $\begin{array}{l}\text { Yuan } \\
\text { et al. }(2008) \\
(\text { China })^{(14)}\end{array}$ & $\begin{array}{l}46 \\
\text { second-year } \\
\text { students }\end{array}$ & PBL & Lectures & 18 weeks & CCTST & $\begin{array}{l}\text { There was a statistically } \\
\text { significant difference } \\
\text { between the PBL and } \\
\text { lecture groups for overall } \\
\text { CT }(\mathrm{p}=0.040) \text { after } \\
\text { intervention }\end{array}$ \\
\hline $\begin{array}{l}\text { Morey } \\
(2012) \\
(\text { USA) })^{(32)}\end{array}$ & $\begin{array}{l}50 \text { students } \\
\text { in their last } \\
\text { semester }\end{array}$ & $\begin{array}{l}\text { Animated Pedagogical } \\
\text { Agents (APA). Using an } \\
\text { online tool, students } \\
\text { performed three case } \\
\text { studies, which they } \\
\text { received in writing and } \\
\text { that were narrated by APA. }\end{array}$ & $\begin{array}{l}\text { Online case } \\
\text { studies }\end{array}$ & & $\begin{array}{l}\text { Critical Thinking } \\
\text { Process Test } \\
\text { (CTPT) }\end{array}$ & $\begin{array}{l}\text { There was no statistically } \\
\text { significant difference } \\
\text { between the overall CT } \\
\text { scores in the groups after } \\
\text { the intervention }(p=0.561)\end{array}$ \\
\hline
\end{tabular}


...continuation

\begin{tabular}{|c|c|c|c|c|c|c|}
\hline $\begin{array}{l}\text { Author (Year) } \\
\text { (country) }\end{array}$ & Sample size & Intervention & Comparison & $\begin{array}{r}\text { Duration of } \\
\text { intervention }\end{array}$ & $\begin{array}{l}\text { Measurement } \\
\text { tools }\end{array}$ & Results \\
\hline $\begin{array}{l}\text { Yu } \\
\text { et al. (2013) } \\
\text { (China) })^{(33)}\end{array}$ & $\begin{array}{l}76 \text { second- } \\
\text { year students }\end{array}$ & $\begin{array}{l}\text { PBL. Because it was an } \\
\text { experimental crossover } \\
\text { study, both groups } \\
\text { received the interventions } \\
\text { PBL and lecture-based } \\
\text { learning (LBL) at different } \\
\text { times }\end{array}$ & LBL & $\begin{array}{c}\text { One } \\
\text { semester }\end{array}$ & $\begin{array}{c}\text { CCTDI-CV } \\
\text { (Chinese version) }\end{array}$ & $\begin{array}{l}\text { The group that learned } \\
\text { first with PBL showed a } \\
\text { statistically significant } \\
\text { increase of overall CT } \\
(p=0.032) \text {, as well as the } \\
\text { second group }(p=0.048)\end{array}$ \\
\hline $\begin{array}{l}\text { Chen } \\
\text { et al. }(2011) \\
\text { (China) }^{(34)}\end{array}$ & $\begin{array}{l}95 \text { second- } \\
\text { year students }\end{array}$ & Concept map + Lectures & Lectures & 15 weeks & $\begin{array}{c}\text { Critical Thinking } \\
\text { Scale (CTS) }\end{array}$ & $\begin{array}{l}\text { No statistically significant } \\
\text { differences were found } \\
\text { between the groups }\end{array}$ \\
\hline $\begin{array}{l}\text { Brown (2008) } \\
\text { (USA) }^{(35)}\end{array}$ & $\begin{array}{l}67 \text { final- } \\
\text { year students }\end{array}$ & $\begin{array}{l}\text { High-fidelity simulation } \\
\text { with the use of HPS } \\
\text { + Debriefing + Role } \\
\text { Modeling }\end{array}$ & $\begin{array}{l}\text { High-fidelity } \\
\text { simulation } \\
\text { with the use } \\
\text { of the HPS + } \\
\text { Debriefing. }\end{array}$ & 4 days & $\begin{array}{l}\text { Professional } \\
\text { Judgment Rating } \\
\text { Form (PJRF) }\end{array}$ & $\begin{array}{l}\text { No statistically significant } \\
\text { differences were found } \\
\text { between the groups }\end{array}$ \\
\hline
\end{tabular}

The teaching strategies used and tested in the RCTs included: PBL, concept map, simulation, reflective writing, Role Modeling and Animated Pedagogical Agents. In the control group, lectures were used in $58.3 \%$ of the studies. The "traditional" strategy already used in the discipline appeared as a resource used in the control group in $25 \%$ of studies. In the remaining $16.7 \%$, the control group's strategy was the same as that used in the intervention group, except for the model that the researcher wanted to test, which were the $\mathrm{APA}^{(32)}$ and Role Modeling ${ }^{(35)}$.

It is notable that in only three studies was the intervention proposed based on a conceptual model, such as the 5E Learning Model ${ }^{(29)}$, Richard Paul's CT Instructional Model $^{(30)}$ and the theoretical model of Role Modeling ${ }^{(35)}$. It is also notable that in only three studies ${ }^{(14,28,31)}$ was it mentioned that the people who implemented the intervention were trained or had experience with the strategy applied.

\section{BIAS RISK}

Bias risks were identified in the studies based on JBI criteria $^{(20)}$ and the Cochrane Collaboration tool (Figure 2) to assess bias risk in $\mathrm{RCTs}^{(36-37)}$.

With regard to selection bias, this was uncertain in 50\% of studies, due to the paucity of data regarding generation of the random sequence, and in only four studies did the authors explicitly state that they maintained the randomization sequence hidden throughout the study period ${ }^{(27-28,31,35)}$.

In regard to performance bias, in none of the studies was it possible to blind the participants, because educational interventions were being investigated. Regarding blinding of the professionals who applied the intervention, in only one study ${ }^{(29)}$ was this described. Blinding of the researcher who analyzed the data was reported in only two studies ${ }^{(31,35)}$.

In regard to attrition bias, $33.4 \%$ of the studies did not perform analysis by intention to treat, and most had no losses in adherence. In reporting bias, most studies showed a low risk of bias.

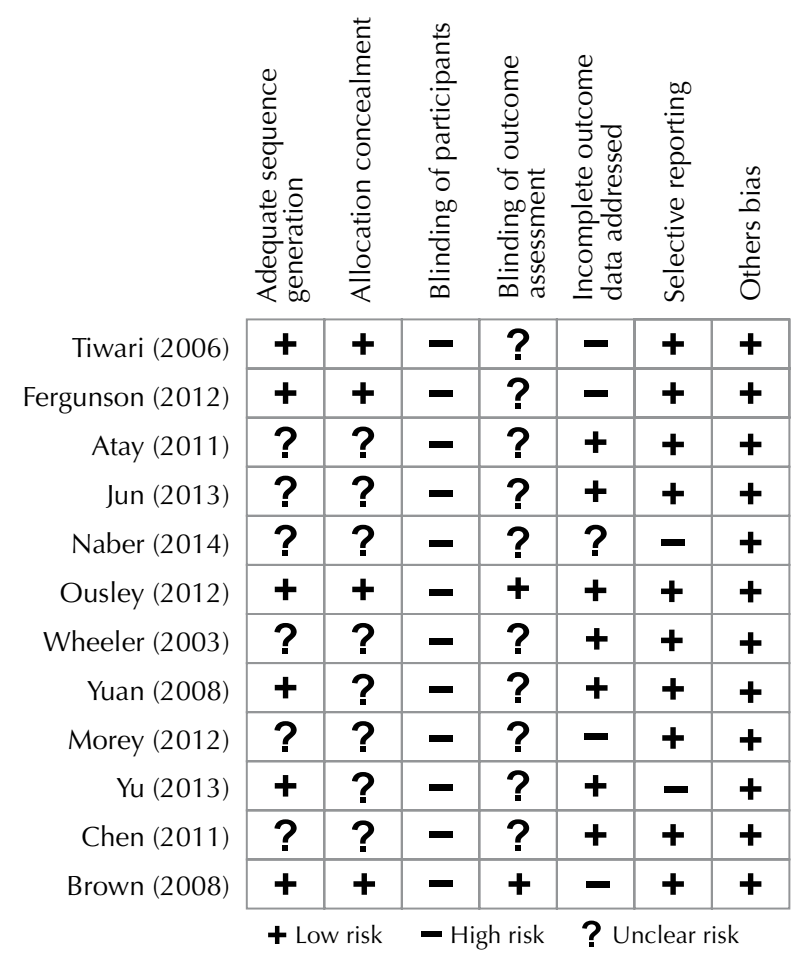

Figure 2 - Summary of the assessment of risk of bias - São Paulo, Brazil, 2015.

\section{Meta-AnAlysis}

Four RCTs were included using PBL as the intervention and lectures on the control group ${ }^{(14,27,29,33)}$. The combination of these studies in a meta-analysis, including 362 participants, demonstrated the effectiveness of PBL ( $\mathrm{SMD}=0.32$, 95\% $\mathrm{CI}=0.08$ to 0.56 ; Overall $\mathrm{Z}=2.67, \mathrm{p}=0.0078$ ) when compared to lectures for the development of overall CT in undergraduate nursing students (Figure 3), with homogeneity being demonstrated (Chi-square $=6.1, \mathrm{p}=0.1068$ ) between the studies. 


$\begin{array}{lc}\begin{array}{l}\text { Author (year) } \\ \text { Tiwari A et al. (2006) }\end{array} & \text { Results } \\ \begin{array}{l}\text { Yuan H et al. (2008) } \\ \text { Yu D et al. (2013) }\end{array} & 21.83(2.74 ; 23) \\ \begin{array}{l}\text { Jun et al. }(2013) \\ \text { Synthesis }\end{array} & 6.34(26.24(9.67 ; 83) \\ & 91.95(120.38 ; 183) \\ \begin{array}{l}\text { Heterogeneity: } \text { Chi }^{2}=6.1(p=0.107) ; t^{2}=0.050 \\ \text { Test for overall effect: } \mathrm{Z}=2.02(p=0.043)\end{array}\end{array}$

Sample size Measure $(\mathrm{Cl}) \quad$ Weight $(\%)$

$\begin{array}{rrr}79 & -0.16(-0.6 ; 0.29) & 22.1 \% \\ 46 & 0.61(0.02 ; 1.21) & 12.28 \% \\ 76 & 0.5(0.04 ; 0.96) & 20.63 \% \\ 161 & 0.16(-0.15 ; 0.47) & 45 \% \\ 362 & 0.21(0.01 ; 0.42) & 100 \%\end{array}$

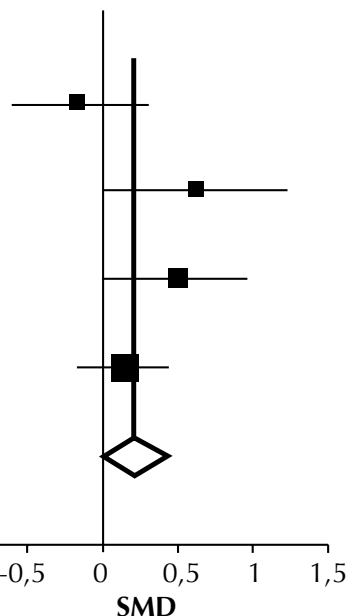

Figure 3 - Meta-analysis of overall CT scores of studies that evaluated the strategy of PBL compared to lectures - São Paulo, SP, Brazil, 2015.

Three RCTs were also included that used the concept map as intervention and traditional teaching on the control group $^{(15-16,34)}$. The combination of these studies in one metaanalysis, including 251 participants, did not demonstrate effectiveness of the concept map (SMD=-0.53, CI 95\%
-0.79--0.28; Overall $Z=4.07, \mathrm{p}<0.0001$ ) when compared to traditional education for development of overall $\mathrm{CT}$ in undergraduate nursing students (Figure 4). It is noteworthy that statistical heterogeneity was identified between the studies $($ Chi-square $=10.82, \mathrm{p}=0.0044)$.

$\begin{array}{lcccc}\text { Author (year) } & \text { Results } & \begin{array}{c}\text { Sample } \\ \text { size }\end{array} & \text { Measure }(\mathbf{C l}) & \text { Weight (\%) } \\ \text { Weeler }(2003) & 16.93(4.37 ; 44) & 76 & -0.14(-0.6 ; 0.31) & 31.50 \% \\ \text { Chen et al. (2011) } & 41.04(5.25 ; 48) & 95 & -0.37(-0.77 ; 0.04) & 39.78 \% \\ \text { Atay S (2011) } & 225.8(19.2 ; 40) & 80 & -1.19(-1.67 ; 0.72) & 28.72 \% \\ \text { Synthesis } & 94.59(7.23 ; 132) & 251 & -0.53(-0.79 ;-0.28) & 100 \%\end{array}$

Heterogeneity: $\mathrm{Chi}^{2}=10.82(\mathrm{p}=0.004) ; \mathrm{t}^{2}=23.243$ Test for overall effect: $Z=4.07(p<0.001)$

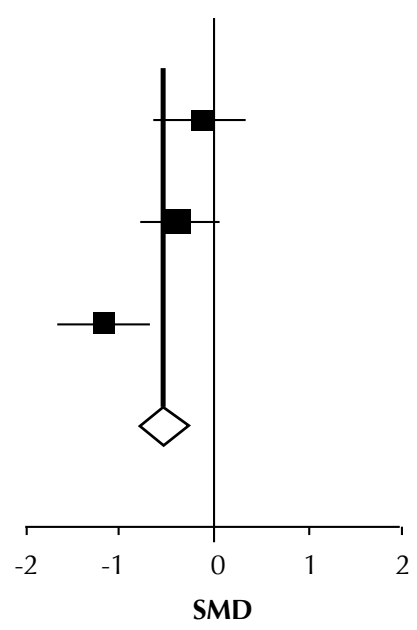

Figure 4 - Meta-analysis of overall CT scores of studies that evaluated the strategy of the concept map compared to traditional teaching - São Paulo, SP, Brazil, 2015.

\section{DISCUSSION}

To the best of the authors' knowledge, this is the first SR that sought to identify the most effective teaching strategies for development of $\mathrm{CT}$ in undergraduate nursing students. Other SR have been developed on this topic, however they sought to: evaluate one strategy in isolation, such as $\mathrm{PBL}^{(17-}$ ${ }^{18)}$ and simulation ${ }^{(19)}$; to identify, in two recent SR, the relationship between learning styles and $\mathrm{CT}^{(38)}$; and, one sought to explore how $\mathrm{CT}$ is perceived by teachers and nursing students through a SR of qualitative studies ${ }^{(9)}$.

From the results of studies that evaluated teaching of PBL and the meta-analysis performed of the RCT that used this teaching strategy, it can be said that PBL demonstrated effectiveness in increasing overall CT scores. This finding corroborates the results of the other two SR conducted that evaluated PBL ${ }^{(17-18)}$. However, the SR for the present study advances knowledge with respect to the previous ones, since it included only the RCT; identified a statistically significant increase in CT skills using PBL, and not only abilities, as suggested in one SR that evaluated the effectiveness of PBL in development of $\mathrm{CT}^{(17)}$. In addition, the meta-analysis for the present study demonstrated greater homogeneity between the studies included in relation to this ${ }^{(17)}$.

The concept map is a widely used teaching strategy and discussed in nursing education ${ }^{(39-40)}$ as a promising tool for development of CT skills, however, there are few 
experimental studies testing its effectiveness. Meta-analysis of the three studies included that used the strategy of concept map compared to the usual teaching method did not demonstrate its benefit, although the studies were identified as heterogeneous, corroborating the findings of another study ${ }^{(41)}$ which performed an uncontrolled trial with the same goal.

In addition to the PBL developed as an isolated teaching strategy, studies have been conducted evaluating the use of PBL associated with concept maps ${ }^{(42-43)}$ and even in webbased learning environments ${ }^{(44)}$. Both demonstrate the benefit of this association for the development of CT in students. Therefore, further studies need to be developed with the combination of different teaching strategies, since, although in this SR the strategy of concept map did not demonstrate effectiveness in the development of CT, studies have shown promising results of its association with $\mathrm{PBL}^{(42-43)}$.

As regards other teaching strategies used (simulation, Role Modeling, reflective writing and APA), none of them proved to be effective to develop CT in undergraduate nursing students. However, isolated studies have been conducted with small samples, and the authors of the present study encourage future research on these strategies that is supported in theoretical models of teaching and learning.

It is no longer acceptable for a nursing instructor to tell their students to think critically, without first providing a detailed explanation of the process and its assumptions ${ }^{(45)}$, since in order to improve CT skills among university students, CT should be taught in the classroom ${ }^{(46)}$. Explicit teaching of CT has been studied in-depth by means of instructional models, in which the teacher teaches the theoretical concepts related to the development of CT capacities and skills, in addition to stimulating the development of these skills. Although the only study included in this $\mathrm{SR}^{(30)}$ that used an instructional model for teaching CT did not show a significant increase in CT scores, studies have shown the effectiveness of this model in the development of CT abilities and skills in college students ${ }^{(46-47)}$. Thus, the authors of the present study encourage research on the effectiveness of the instructional model combined with other teaching strategies, and highlight the need for a theoretical model of CT that better instructs teachers on instruction of CT for undergraduate nursing students.

Regarding instruments to evaluate CT, although all of those which were used in this SR have proven their validity and reliability according to statistical tests, only two studies used specific instruments for nursing students ${ }^{(29,32)}$, given the shortage of scales available in the literature. Therefore, there is a pressing need to develop tools to evaluate CT for undergraduate nursing students, and to consider the aspects inherent to the science and profession of nursing.

Another important issue discussed is the influence of culture in the use of PBL to promote $\mathrm{CT}^{(48)}$. In this $\mathrm{SR}$, of the four studies that tested the use of PBL for the development of CT, three were developed in China and one in South Korea. This seems to be an important aspect to consider with regard to the external validity of the studies included in this SR, which demonstrated the effectiveness of PBL, since the cultures of Asian countries greatly differ from those in the West. Thus, the authors of the present study encourage the development of further experimental studies in Western countries to assess the most effective strategies for teaching CT. In this sense, we believe that the next steps of the multicenter project of the RIIEE will contribute to these demands, especially in Latin America, because it will enable approximation of different cultures in the context of an international network.

For teaching in nursing, the authors believe that this SR enables reflection on teaching practice in the training of nurses capable of thinking critically. Thus, the authors encourage teachers to implement, develop and research new teaching strategies to promote CT in nursing students. The findings of the present study demonstrated the effectiveness of PBL when the JBI guidelines were used as a methodological reference, because JBI is an organization internationally recognized for development of SR, since a comprehensive search of the published and unpublished literature was performed, and only studies with the highest level of evidence (RCT) were included, reflecting the credibility of the findings.

As a secondary study, the SR is limited to the availability of data from the primary studies included. In this way, the following limitations of this SR were identified: the difficulty in finding adequate information about the type of study design in the abstracts, as the authors put very different nomenclatures to designate experimental studies, particularly RCT, which may have produced a risk of search bias in this SR; there are several tools used to evaluate CT, few of which were specific to nursing, so that the validity and reliability of different instruments may have influenced the measurement of the outcome; finally, the difficulty of contacting authors to answer questions that would determine the inclusion of studies in the SR, which led to the exclusion of some studies due to lower methodological quality. It should be noted that for this SR, contact was attempted with six authors to obtain further information, though responses were obtained from only two.

As implications for future research, the authors of the present study believe the following to be necessary: clarification of the concept of CT in nursing literature; development and evaluation of teaching strategies that are based on instructional models of teaching CT; development of studies with larger, high-quality sample sizes, to withstand the effects it proposes to prove, using a pre- and post-test randomized format to control internal and external threats to the validity of the study; researchers who apply the intervention must be trained, and a standardized intervention needs to be applied, so that nurses need to develop the intervention method according to their actual educational context; and, it is urgent to develop an instrument capable of evaluating the development of CT, which considers the aspects inherent to the science and profession of nursing.

\section{CONCLUSION}

The teaching strategies used and tested in the RCT with the aim of developing CT in undergraduate nursing students included PBL, the concept map, simulation, reflective 
writing, Role Modeling and Animated Pedagogical Agents. Furthermore, based on the meta-analysis of the studies included, the effectiveness of PBL was demonstrated in the increased overall CT scores from homogeneous studies. This result confirmed our hypothesis that the teaching strategies that show better efficacy in RCT are those that involve the use of active methodologies.
Further studies need to be undertaken in order to develop, implement and evaluate new teaching strategies, as well as to test existing strategies in different cultures, to develop CT in undergraduate nursing students that are guided by high methodological rigor, supported in theoretical teaching and learning models, and developed in multicenter research projects.

\section{RESUMO}

Objetivo: Avaliar a efetividade das estratégias de ensino utilizadas para o desenvolvimento do pensamento crítico (PC) em estudantes de graduação em Enfermagem. Método: Revisão sistemática com metanálise baseada nas recomendações do Joanna Briggs Institute. A busca foi realizada nas bases de dados PubMed, CINAHL, EMBASE, Web of Science, SCOPUS, LILACS, Cochrane CENTRAL, PsycINFO e ERIC e de banco de teses dos quatro continentes. A seleção e avaliação inicial dos estudos e a avaliação da qualidade metodológica foi realizada por dois revisores de forma independente. Resultados: Incluídos 12 ensaios clínico randomizados. Na metanálise, dos quatro estudos incluídos que avaliaram a estratégia do Problem Based Learning (PBL), comparada a palestras, foi demonstrada a efetividade do PBL, estatisticamente significativa ( $\mathrm{SMD}=0,21$ e $95 \% \mathrm{IC}=0,01-0,42 ; \mathrm{p}=0,0434$ ) para o desenvolvimento do PC em estudantes de graduação em Enfermagem e os estudos eram homogêneos (Qui-quadrado=6,10, p=0,106). Conclusão: Foi demonstrada a efetividade do PBL no aumento dos escores de PC global. Novos estudos precisam ser feitos com o objetivo de desenvolver, implementar e avaliar estratégias de ensino, que sejam pautadas em alto rigor metodológico e amparadas em modelos teóricos de ensino-aprendizagem.

\section{DESCRITORES}

Pensamento; Estudantes de Enfermagem; Educação em Enfermagem; Ensaio Clínico Controlado Aleatório; Revisão.

\section{RESUMEN}

Objetivo: Evaluar la efectividad de las estrategias de enseñanza utilizadas para el desarrollo del pensamiento crítico (PC) de estudiantes de pregrado de Enfermería. Método: Revisión sistemática con metaanálisis basado en las recomendaciones del Joanna Briggs Institute La búsqueda fue realizada en las bases de datos PubMed, CINAHL, EMBASE, Web of Science, SCOPUS, LILACS, Cochrane CENTRAL, PsycINFO y ERIC, y de banco de tesis de los cuatro continentes. La selección y evaluación inicial de los estudios y la evaluación de la calidad metodológica las llevó a cabo dos revisores de modo independiente. Resultados: Incluidos 12 ensayos clínicos randomizados. En el metaanálisis, de los cuatro estudios incluidos que evaluaron la estrategia del Problem Based Learning (PBL), comparada con conferencias, fue demostrada la efectividad del PBL, estadísticamente significativa (SMD=0,21 y el 95\% IC=0,01-0,42; $\mathrm{p}=0,0434)$ para el desarrollo del PC en estudiantes de pregrado en Enfermería, y los estudios eran homogéneos (Chi cuadrado=6,10, $\mathrm{p}=0$,106). Conclusión: Fue demostrada la efectividad del PBL en el incremento de los puntajes de PC global. Se necesitan hacer nuevos estudios con el fin de desarrollar, implantar y evaluar estrategias de enseñanza que se pauten en un alto rigor metodológico y se amparen en modelos teóricos de enseñanza-aprendizaje.

\section{DESCRIPTORES}

Pensamiento; Estudiantes de Enfermería; Educación en Enfermería; Ensayo Clínico Controlado Aleatório; Revisión.

\section{REFERENCES}

1. Chang MJ, Chang YJ, Kuo SH, Yang YH, Chou FH. Relationships between critical thinking ability and nursing competence in clinical nurses. J Clin Nurs [Internet]. 2011 [cited 2015 Aug 10];20(21-22):3224-32. Available from: http://onlinelibrary.wiley.com/doi/10.1111/j.13652702.2010.03593.x/pdf

2. Pitt V, Powis D, Levett-Jones T, Hunter S. The influence of critical thinking skills on performance and progression in a pre-registration nursing program. Nurse Educ Today [Internet]. 2015 [cited 2015 Aug 16];35(1):125-31. Available from: http://dx.doi.org/10.1016/j. nedt.2014.08.006

3. Choi E, Lindquist R, Song Y. Effects of problem-based learning vs. traditional lecture on Korean nursing students critical thinking, problemsolving, and self-directed learning. Nurse Educ Today [Internet]. 2014 [cited 2015 Sept 04];34(1):52-6. Available from: http://www. sciencedirect.com/science/article/pii/S0260691713000695

4. Ozkahraman S, Yildirim B. An overview of critical thinking in nursing and education. Am Int J Contemp Research [Internet]. 2011 [cited 2015 Sept 02];1(2):190-6. Available from: http://www.aijcrnet.com/journals/Vol_1_No_2_September_2011/25.pdf.

5. Borglin, G. Promoting critical thinking and academic writing skills in nurse education. Nurse Educ Today [Internet]. 2012 [cited 2015 Aug 10];32(5):611-13. Available from:_http://www.sciencedirect.com/science/article/pii/S0260691711001675

6. Paul SA. Assessment of critical thinking: a Delphi study. Nurse Educ Today [Internet]. 2012 [cited 2015 Aug 09];34(11):1357-60. Available from:__http://dx.doi.org/10.1016/j.nedt.2014.03.008 0260-6917

7. Bensley A, Spero RA. Improving critical thinking skills and metacognitive monitoring through direct infusion. Thinking Skills Creativity [Internet]. 2014 [cited 2015 Aug 10];12:55-68. Available from: http://www.sciencedirect.com/science/article/pii/S1871187114000066.

8. Papathanasiou IV, Kleisiaris CF, Fradelos EC, Kakou K, Kourkouta L. Critical thinking: the development of an essential skill for nursing students. Acta Inform Med [Internet]. 2014 [cited 2015 Aug 06];22(4):283-286. Available from: http://www.ncbi.nlm.nih.gov/pmc/articles/ PMC4216424/

9. Chan ZCY. A systematic review of critical thinking in nursing education. Nurse Educ Today [Internet]. 2013 [cited 2015 Aug 10];33(3):23640. Available from: http://www.sciencedirect.com/science/article/pii/S0260691713000087 
10. Azizi-Fini I, Hajibagheri A, Adib-Hajbaghery M. Critical thinking skills in nursing students: a comparison between freshmen and senior students. Nurs Midwifery Stud [Internet]. 2015 [cited 2015 Aug 10];4(1):e25721. Available from: http://www.ncbi.nlm.nih.gov/pmc/ articles/PMC4377532/.

11. Huang GC, Newman LR, Schwartzstein RM. Critical thinking in health professions education: summary and Consensus Statments of the Millennium Conference 2011. Teach Learn Med [Internet]. 2014 [cited 2015 Aug 08];26(1):95-102. Available from: http://www. tandfonline.com/doi/pdf/10.1080/10401334.2013.857335

12. Ozturk C, Muslu GK, Dicle A. A comparison of problem-based and traditional education on nursing students' critical thinking dispositions. Nurse Educ Today [Internet]. 2008 [cited 2015 July 28];28(5):627-32. Available from: http://www.sciencedirect.com/science/article/pii/ S0260691707001529\#

13. Lyons EM. Examining the effects of problem-based learning and NCLEX-RN scores on the critical thinking skills of associate degree nursing students in a Southeastern Community College. Int J Nurs Educ Scholarsh [Internet]. 2008 [cited 2015 Jun 24];5(1):1-17. Available from: http://www.degruyter.com/view/j/ijnes.2008.5.issue-1/ijnes.2008.5.1.1524/ijnes.2008.5.1.1524.xml

14. Yuan D, Kunaviktikul W, Klunklin A, Williams BA. Improvement of nursing students' critical thinking skills through problem-based learning in the People's Republic of China: a quasi-experimental study. Nurs Health Sci [Internet]. 2008 [cited 2015 Sept 01];10(1):70-6. Available from: http://onlinelibrary.wiley.com/doi/10.1111/j.1442-2018.2007.00373.x/epdf

15. Atay S, Karabacak U. Care plans using concept maps and their effects on the critical thinking dispositions of nursing students. Int J Nurs Pract [Internet]. 2012 [cited 2015 Aug 18];18(3):233-9. Available from: http://onlinelibrary.wiley.com/doi/10.1111/j.1440-172X.2012.02034.x/epdf.

16. Wheeler LA, Collins SKR. The influence of concept mapping on critical thinking in baccalaureate nursing students. J Prof Nurs [Internet]. 2003 [cited 2015 Aug 22];19(6), 339-46. Available from: http://www.sciencedirect.com/science/article/pii/S8755722303001340.

17. Kong LN, Qin B, Zhou YQ, Mou SY, Gao HM. The effectiveness of problem-based learning on development of nursing students' critical thinking: a systematic review and meta-analysis. Int J Nurs Stud [Internet]. 2014 [cited 2015 Aug 08];51(3):458-69. Available from: http:// www.sciencedirect.com/science/article/pii/S0020748913001910

18. Yuan H, Willians BA, Fan L. A systematic review of selected evidence on developing nursing students critical thinking through problembased learning. Nurse Educ Today [Internet]. 2008 [cited 2015 Aug 20];28(6):657-63. Available from: http://www.sciencedirect.com/ science/article/pii/S026069170700175X

19. Cant RP, Cooper SJ. Simulation-based learning in nurse education: systematic review. J Adv Nurs [Internet]. 2010 [cited 2015 Sept 02];66(1):3-15. Available from: http://onlinelibrary.wiley.com/doi/10.1111/j.1365-2648.2009.05240.x/epdf

20. Joanna Briggs Institute (JBI). Joanna Briggs Institute Reviewer's Manual [internet]. Adelaide; 2014 [cited 2014 June 02]. Available from: http://joannabriggs.org/assets/docs/sumari/ReviewersManual-2014.pdf

21. Moher D, Liberati A, Tetzlaff J, Altman DG. Preferred reporting items for systematic reviews and meta-analyses: the PRISMA statment. Plos Med [Internet]. 2009 [cited 2015 Aug 04];6(7):1-6. Available from: http://www.plosmedicine.org/article/fetchObject. action?uri=info:doi/10.1371/journal.pmed.1000097\&representation=PDF

22. Oliveira LB, Püschel VAA, Díaz LJR, Cruz DALM. The effectiveness of teaching strategies for the development of critical thinking in nursing undergraduate students: a systematic review protocol. JBI Database System Rev Implement Rep [Internet]. 2015 [cited 2015 Aug 22];13(2):26-36. http://joannabriggslibrary.org/index.php/jbisrir/article/view/1073/2379

23. Oliveira LB, Püschel VAA, Díaz LJR, Cruz DALM. The effectiveness of teaching strategies for the development of critical thinking in nursing undergraduate students: a systematic review protocol. PROSPERO 2015: CRD42015019034 Available from: http://www.crd.york.ac.uk/ PROSPERO/display_record.asp?ID=CRD42015019034.

24. Tang L, Sung H. The effectiveness of problem-based learning on nursing students' critical thinking: a systematic review. JBI Database of System Rev Implement Rep [Internet]. 2012 [cited 2015 Aug 19];10(57):3907-16. Available from: http://www.joannabriggslibrary.org/ index.php/jbisrir/article/view/14/27

25. Carter AG, Creedy DK, Sidebothama M. Evaluation of tools used to measure critical thinking development in nursing and midwifery undergraduate students: a systematic review. Nurse Educ Today [Internet]. 2015 [cited 2015 Aug 26];35:864-74. Available from: http:// www.sciencedirect.com/science/article/pii/S0260691715000994

26. Ried K. Interpreting and understanding meta-analysis graphs: a practical guide. Aust Fam Physician [Internet]. 2006 [cited 2015 Aug 10];35(8):635-8. Available from: http://www.racgp.org.au/afpbackissues/2006/200608/20060805ried.pdf

27. Tiwari A, Lai P, So M, Yuen K. A comparison of the effects of problem-based learning and lecturing on the development of students' critical thinking. Med Educ [Internet]. 2006 [cited 2015 Aug 26];40(6):547-54. Available from: http://onlinelibrary.wiley.com/doi/10.1111/j.13652929.2006.02481.x/epdf

28. Ferguson RA. Critical thinking skills in nursing students: using Human Patient Simulation [thesis]. California: Northern California University; 2012.

29. Jun WH, Lee EJ, Park HJ, Chang AK, Kim MJ. Use of the 5E learning cycle model combined with Problem-Based Learning for a fundamentals of nursing course. J Nurs Educ. 2013;52(12): 681-9.

30. Naber J, Wyatt TH. The effect of reflective writing interventions on the critical thinking skills and dispositions of baccalaureate nursing students. Nurse Educ Today [Internet]. 2014 [cited 2015 Aug 26];34(1),67-72. Available from: http://www.sciencedirect.com/science/ article/pii/S0260691713001251

31. Ousley TL. The Development of Critical Thinking with Technology in Nursing Education [thesis]. Chicago: Northcentral University; 2012.

32. Morey DJ. Development and evaluation of web-based animated pedagogical agents for facilitating critical thinking in nursing. Nurs Educ Perspect. 2012;33(2):116-20.

33. Yu D, Zhang Y, XuY, Wu J, Wang C. Improvement in critical thinking dispositions of undergraduate nursing students through problem-based learning: a crossover-experimental study. J Nurs Educ. 2013;52(10):574-81.

34. Chen S, Liang T, Lee M, Liao IC. Effects of concept map teaching on students' critical thinking and approach to learning and studying. J Nurs Educ. 2011:50(8):466-9. 
35. Brown SC. The impact of high fidelity simulation and role modeling in the acquisition of critical thinking skills and self-efficacy: an experimental study [thesis]. Colorado: University of Northern; School of Nursing, College of Natural and Health Sciences; 2008.

36. Carvalho APVC, Silva V, Grande A. Avaliação do risco de viés de ensaios clínicos randomizados pela ferramenta da colaboração Cochrane. Rev Diagn Tratamento. 2013;18(1):38-44.

37. Higgins JPT, Green S, editors. Cochrane Handbook for Systematic reviews of interventions. Version 5.1.0, updated March 2011 [Internet]. Geneva: The Cochrane Collaboration; 2011 [cited 2015 Aug 26]. Available from: www.cochrane-handbook.org

38. Andreou C, Papastravou E, Merkouris A. Learning styles and critical thinking relationship in baccalaureate nursing education: a systematic review. Nurse Educ Today [Internet]. 2014 [cited 2015 Aug 16];34(3):362-71. Available from: http://www.sciencedirect.com/science/ article/pii/S0260691713002049

39. Senita J. The use of concept maps to evaluate critical thinking in the clinical setting. Teach Learn Nurs [Internet]. 2008 [cited 2015 Aug 08];3(1):6-10. Available from: http://www.sciencedirect.com/science/article/pii/\$1557308707000844

40. Gerdeman JL, Lux K, Jacko J. Using concept mapping to build clinical judgment skills. Nurse Educ Pract [Internet]. 2013 [cited 2015 Aug 10]; 13(1):11-7. Available from: http://www.sciencedirect.com/science/article/pii/S1471595312001047

41. Lee W, Chiang CH, Liao IC, Lee ML, Chen SL, Liang T. The longitudinal effect of concept map teaching on critical thinking of nursing students. Nurse Educ Today [Internet]. 2013 [cited 2015 Aug 10];33(10):1219-23. Available from: http://www.sciencedirect.com/science/ article/pii/S0260691712001992

42. Tseng H, Chou F, Wang H, Ko H, Jian S, Weng W. The effetiveness of problem-based learning and concept mapping among Taiwanese registred nursing studets. Nurs Educ Today [Internet]. 2011 [cited 2015 Aug 22];31(8):41-6. Available from: http://www.sciencedirect.com/ science/article/pii/S0260691710002467

43. Orique SB, McCarthy MA. Critical thinking and the use of nontraditional instructional methodologies. J Nurs Educ .2015;54(8):455-9.

44. Crawford TR. Using problem-based learning in web-based components of nurse education. Nurse Educ Pract [Internet]. 2011 [cited 2015 Aug 22];11(2):124-30. Available from: http://www.sciencedirect.com/science/article/pii/S1471595310001368

45. Lovatt A. Defining critical thoughts. Nurse Educ Today [Internet]. 2014 [cited 2015 Sept 02];34(5):670-2. Available from: http://www. sciencedirect.com/science/article/pii/S0260691713004255

46. Niu L, Behar-Horenstein LS, Garvan CW. Do instructional interventions influence college students' critical thinking skills? A metaanalysis. Rev Educ Res [Internet]. 2013 [cited 2015 Aug 22];9:114-128. Available from: http://www.sciencedirect.com/science/article/ pii/S1747938X1300002X

47. Abrami PC, Bernard RM, Borokhovski E, Wade A, Surkes MA, Tamim R, et al. Instructional Interventions Affecting Critical Thinking Skills and Dispositions: A Stage 1 Meta-Analysis. Rev Educ Res [Internet]. 2008 [cited 2015 Aug 08];78(4):1102-34. Available from: http://www. physics.emory.edu/faculty/weeks//journal/abrami-rer08.pdf

48. Sommers CL. Considering culture in the use of problem-based learning to improve critical thinking - Is it important? Nurse Educ Today [Internet]. 2014 [cited 2015 Aug 10];34:110911. Available from: http://www.sciencedirect.com/science/article/pii/S0260691714001038 